\title{
RCRA Corrective Action Determination of No Further Action
}

\begin{abstract}
BACKGROUND: On July 27, 1990, the U.S. Environmental Protection Agency (EPA) proposed a regulatory framework (55 FR 30798) for responding to releases of hazardous waste and hazardous constituents from solid waste management units (SWMUs) at facilities seeking permits or permitted under the Resource Conservation and Recovery Act (RCRA). The proposed rule, "Corrective Action for Solid Waste Management Units at Hazardous Waste Facilities," would create a new Subpart S under the 40 CFR 264 regulations, and outlines requirements for conducting RCRA Facility Investigations, evaluating potential remedies, and selecting and implementing remedies (i.e., corrective measures) at RCRA facilities.
\end{abstract}

EPA anticipates instances where releases or suspected releases of hazardous wastes or constituents from SWMUs identified in a RCRA Facility Assessment, and subsequently addressed as part of required RCRA Facility Investigations, will be found to be non-existent or non-threatening to human health or the environment. Such releases may require no further action. For such situations, EPA proposed a mechanism for making a determination that no further corrective action is needed. This mechanism is known as a Determination of No Further Action (DNFA) (55 FR 30875). This Information Brief describes what a DNFA is and discusses the mechanism for making a DNFA. This is one of a series of Information Briefs on RCRA corrective action.

STATUTE: $\quad$ RCRA, as amended by the Hazardous and Solid Waste Amendments of 1984 (HSWA).

REGULATIONS: Proposed 40 CFR Part 264, Subpart S (55 FR 30798, July 27, 1990), 40 CFR Part 270.

REFERENCES: 1. RCRA Corrective Action Program Guide (Interim), U.S. Department of Energy, Office of Environmental Policy and Assistance, RCRA/CERCLA Division (EH-413), Guidance Manual, DOE/EH-0393, May 1993.

2. "RCRA Facility Assessments," U.S. Department of Energy, Office of Environmental Policy and Assistance, RCQRACERCLA Division (EH-413), Information Brief, EH-231-014/0794, July 1994.

3. "RCRA Facility Investigations," U.S. Department of Energy, Office of Environmental Policy and Assistance, RCRAVCERCLA Division (EH-413), Information Brief, EH-231-046/1194, November 1994.

4. "RCRA Corrective Action Permit Requirements and Modifications Under Subpart S Rule," U.S. Department of Energy, Office of Environmental Policy and Assistance, RCRA/CERCLA Division (EH-413), Information Brief, EH-231-023/0793 (July 1993).

5. "RCRA Corrective Action Permit Requirements and Modifications Under Subpart F Regulations," U.S. Department of Energy, Office of Environmental Policy and Assistance, RCRA/CERCLA Division (EH-413), Information Brief, EH-231-022/0793 (July 1993).
What is a Determination of No Further Action (DNFA)?

Under proposed 40 CFR 264.514, EPA has proposed a mechanism by which a permittee may request a permit modification to effectively terminate further corrective action at solid waste discernible unit in which solid wastes have been placed at any time, unit was intended for the management of solid or hazardous wastes (proposed 40 CFR 264.501). Examples of SWMUs include, but are not limited to landfills, suiface impoundments, and sumps. management units (SWMUs). This proposed mechanism is known as a Determination of No Further Action (DNFA).

A SWMU is defined as any irrespective of whether the storage areas, waste piles,

\section{When is a DNFA made?}

A DNFA may be made in those cases where a release or suspected release identified in a RCRA Facility Assessment (RFA) or RCRA Facility Investigation (RFI) is found to be either nonexistent or to not pose a threat to human health or the environment (55 FR 30813). This will usually occur upon completion of the RFI and prior to the initiation of the Corrective Measure Study (CMS) phase of the RCRA corrective action process. 
The conditions necessary for making a DNFA include the following (ref. 1):

There is no release or threatened release of a RCRA hazardous waste or hazardous waste constituent from a SWMU;

the substance released is not a hazardous waste or hazardous waste constituent;

the release is not from a SWMU;

$\checkmark$ the release is a permitted release, regulated under another authority, and the EPA or authorized States may pursue actions required under other authorities;

$\square$ the release does not pose a threat to human health or the environment [e.g., the contamination is in a highly saline (Class III) aquifer, the ground water is otherwise unusable by humans, or releases containing

contaminants are at levels that are insignificant as compared to existing background levels (55 FR 30813.)];

Note: Action levels are health-and environmentally-based concentration levels used by EPA or an authorized

the contamination in ground water can be shown to have originated from a source outside the facility;

a the release exceeds action levels, but the EPA or the authorized State determines a CMS is not required; or

$\square$ the release is below action levels established in the RFI.

\section{How is a DNFA made?}

For SWMUs at RCRA-permitted facilities, a DNFA is made via a Class III permit modification (40 CFR Part 270.42, ref. 4). DOE, as the permittee, will initiate a request for the modification of the facility permit to terminate corrective actions for SWMUs requiring no further action. This request will be in the form of an application for a permit modification [proposed 40 CFR 264.514(a)(1)]. The application for a permit modification must contain information which demonstrates that there are no releases of

\section{Class III Permit Modification Requirements [40 CFR 270.42(c)]}

- Notifying all parties on the facility mailing list and the appropriate State and local governmental entities of the proposed change;

- publishing a notice for public comment in a newspaper, including an announcement of a 60-day public comment period, and the date, time, and location of an informational public meeting;

- conducting a 60-day public comment period;

- holding an informational public meeting on the request for permit modification; and

- placing a copy of the proposed modified permit and supporting documents in a publicly-accessible location near the facility.

hazardous waste (including hazardous constituents) from SWMUs that pose a threat to human health and the environment [proposed 40 CFR 264.514(a)(2)]. EPA or the authorized State will review all available information, including comments received during the public comment period. A DNFA will be made by EPA or the authorized State after they determine that the release(s), or suspected release(s), either do not exist or do not pose a threat to human health or the environment. EPA or the authorized State will then grant the requested permit modification [264.514(b)].

\section{Does a DNFA always mean no further action?}

Not necessarily. Under proposed Section 264.514(c)(1), EPA or the authorized State can require additional corrective action investigations or studies at a later date should new information or additional analysis indicate that there is, or may be, a release from a SWMU that poses a threat to human health or the environment.

In addition, a DNFA does not preclude EPA or the authorized State from requiring DOE facilities to conduct continuous or periodic monitoring when site-specific circumstances indicate that releases are likely to occur in the future [proposed 40 CFR 264.514(c)(2)]. For example, EPA or the authorized State may require continuous monitoring of ground water in the vicinity of a SWMU if it can be reasonably expected, based on 
site-specific conditions, that releases to the ground water may occur within the next several years.

\section{How are investigations of a SWMU initiated after a DNFA has been made?}

Should EPA or the authorized State subsequently determine that a new investigation or remediation is required at a RCRA facility, and if a DNFA has already been made, EPA or the authorized State may initiate a major permit modification under 40 CFR 270.41 to require further actions (55 FR 30850).

\section{Is a DNFA facility-specific or SWMU-specific?}

Section 264.514 of the Subpart S proposed rule (55 FR 30813) provides a mechanism whereby the facility permit may be modified where releases or suspected releases that are identified in a RFA and subsequently addressed as part of the required remedial investigations, are found to be nonexistent or of such a nature that they do not pose a threat to human health or the environment. While the language in the rule appears to be facility-specific, it does not specifically preclude a DNFA for individual SWMUs. The decision to apply a DNFA to an individual SWMU or the facility as a whole will be made on a case-by-case basis by the EPA Region or authorized State.

\section{What is the relationship among a DNFA, a determination of technical impracticability, and completion of remedies?}

While determinations of no further action, technical impracticability, and completion of remedies all result in the cessation of remedial activities, there are significant differences in the basis for and timing of these actions:

- A determination of no further action will typically be made after the RFI because the SWMU is found to either not be releasing hazardous wastes or constituents, or because the release is determined to not pose a hazard to human health or the environment (proposed 40 CFR 264.514). A DNFA does not preclude the Regional Administrator or authorized State Director from modifying the permit at a later. date to require corrective action should new information or subsequent analysis indicate there are, or are likely to be, releases from SWMUs at the facility.

A determination of technical impracticability is typically made either after the RFI or during the actual implementation of the remedy. In either case, the determination is made because remediation to media cleanup standards is technically impracticable. Please note that the Regional Administrator or authorized State Director may modify the permit to (1) require the implementation of additional measures to control exposures of humans and the environment to residual contamination, or (2) establish alternate cleanup levels which are technically practicable and consistent with the overall objectives of the remedy (proposed 40 CFR 264.531).

Completion of remedies differs from both the determination of no further action and a determination of technical impracticability in that remedies are completed when media cleanup standards or alternative levels-all actions to control the source of contamination-have been implemented, and procedures for removal, decontamination, closure or post-closure care of units, equipment, or structures required to implement the remedy have been complied with. In this case, the SWMU release is cleaned and no longer presents a hazard to human health or the environment (proposed 40 CFR 264.530).

\section{DOE's Office of Environmental Policy and Assistance, RCRA/CERCLA Division (EH-413) has developed guidance documents that address DOE's requirements and responsibilities under RCRA. EH-413 also can provide on-site support ranging from workshops to technical assistance projects.}

Questions of policy or questions requiring policy decisions will not be dealt with in EH-413 Information Briefs unless that policy has aiready been established through appropriate documentation. Please direct any questions concerning the subject matter covered in this Information Brief to Mr. Jerry Coalgate, RCRAVCERCLA Division, EH-413 (202) 586-6075.

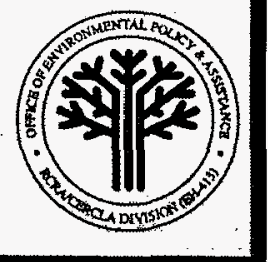




\section{DISCLAIMER}

Portions of this document may be illegible in electronic image products. Images are produced from the best available original document. 
U.S. Department of Energy

Reisa Kall (EH-413)

1000 Independence Ave., S.W.

Washington, DC 20585-0119

(fold here) ---------

Official Business

ADDRESS CORRECTION REQUESTED

FIRST-CLASS MAIL

U.S. POSTAGE

PAID

MERRIFIELD, VA

PERMIT NO. 1635 